\title{
The Effects of Pre-service Teachers' Cognitive Styles on Learning Approaches
}

\author{
Sedat Altintaş, İzzet Görgen \\ Department of Curriculum and Instruction, Mugla Sitkı Koçman University, Turkey
}

\begin{tabular}{l}
\hline \hline Article Info \\
\hline Article history: \\
Received Sep 26, 2018 \\
Revised Oct 3, 2018 \\
Accepted Oct 17, 2018 \\
\hline
\end{tabular}

Keyword:

Field dependent

Field independent

Learning approaches

Pre-service Teachers

\begin{abstract}
The main purpose of the study is to investigate the effects of prospective teachers' cognitive styles on learning approaches. It is aimed to define whether exist significance differences between defining prospective teachers' cognitive styles and learning approaches and demographic variables within the scope of the mean purpose. The study, designed according to correlational survey model, was conducted at Mugla Sitki Kocman University, Faculty of Education in the 2014-2015 academic year spring semester. As data collection instruments, "The Group Embedded Figures Test" was administered to define prospective teachers' cognitive style in the study. On the other hand "The Revised Two Factor Study Process Questionnaire" was used to reveal prospective teachers' learning approaches. According to the findings, prospective teachers generally have field dependent cognitive style. It is determined that between with prospective teachers' gender and academic success and cognitive style scores there isn't any significant difference revealed. However, there is significant difference between branches and cognitive style scores. It has been viewed that prospective teachers prefer deep learning approach generally. There isn't significant difference between gender and learning approaches yet there is significant difference between learning approaches-branches and academic success. It is also concluded that as prospective teachers' cognitive styles approaches to field independent, deep learning approach preference of prospective teachers has diminished.
\end{abstract}

Copyright (C) 2018 Institute of Advanced Engineering and Science. All rights reserved.

\section{Corresponding Author:}

Sedat Altintaş,

Department of Curriculum and Instruction,

Mugla Sitkı Koçman University,

Kotekli, Mugla County 48000, Turkey.

Email: sedataltintas@mu.edu.tr

\section{INTRODUCTION}

People are different from each other as regarding their natures. In modern education, individual differences have a significant role [1]. The perceptions of learners on how they overtake learning tasks and how they are influenced by the learning process have a crucial effect on learning products [2]. Both teachers' and learners' knowledge on individual differences and the usage of them in a learning environment is a significant element on learning prominently. One of the most important factors for individual differences is determined as learning styles that are preferred by learners. There are a number of learning styles that can be used by learners such as thinking styles, learning styles and cognitive styles. For these three basic styles; the way by which learners can learn materials is defined as learning styles; the way in which learners can think about materials is determined as thinking styles and lastly the way that is about how knowledge is acquired is called as cognitive styles.

In the cognitive style theory that is developed by Witkin, Moore, Googenough and Cox [3], two styles have been defined that were called as field-dependent and field-independent. Cognitive style is used to 
refer the learning, organizing, supplying permanence and preferences for a new learnt knowledge. Witkin, Oltman, Raskin and Karp [4] state the term cognitive styles in terms of psychological differences as follows: learners' cognitive style that consists of the different perspectives for each events that have been practiced in the past, the analysis of each new object even alive or inanimate in order to find differences and the tendency to understand objects in the environment in an analytic way is defined as "field-independent" style; the cognitive style in which people obey rules passively and they are heavily influenced by their environment, additionally they tend to understand objects as total is defined as "field-dependent" style. The cognitive style is based on finding the problem-solving techniques of people [3]. In this way, it is a real that people who have different cognitive styles have different learning techniques. It is helpful to know different cognitive styles of learners by teachers in order to identify their learners well and to prepare effective teaching methods for their learners.

The term learning approaches is firstly used by Maton and Saljö [5] in a study that was conducted to understand how learners could acquire a reading text and how they could learn in their learning process. In that study that was conducted by university students, it was concluded that some of the students thought that the reading text was a total version of information units by which they could memorize the knowledge in order to answer the follow-up questions. The other participants who had participated in that study believed that the reading text was a whole version of information and they tried to understand the main points of the text. At the end of that study, it was concluded that the second group that was mentioned above could answer the questions better that the others and they could get the messages that were given in the texts. Marton and Saljo called the first learning approach that was based on memorization as "Surface" and the second one that was based acquisition as "Deep" learning style. The approach that students' take to learning is an important factor influencing the quality of those students' learning outcomes [6]. Deep learning approach leads to real understanding of the subject, and deep and stable learning but surface approach focuses on memorizing information and results in incomplete understanding [7].

\section{RESEARCH METHOD}

This study was a descriptive research model that was designed via relational screening model. The descriptive survey model is a research model that is aimed to define the events in the past and present as bare facts. The research problem that consists of events, humans or objects is aimed to be identified how it makes in the real world [8].

\subsection{Research Sample}

The universe of this study was determined as the pre-service teachers who have been teaching in Faculty of Education in Mugla Sitki Kocman University in 2014-2015 spring semester. As for the sample of this study, 3rd grade students were selected. The variables of the sample group are given in Table 1.

Table 1. The range of the sample in terms of variables

\begin{tabular}{llcc}
\hline Variable & Group & $\mathrm{N}$ & $\%$ \\
\hline \multirow{2}{*}{ Gender } & Female & 247 & 63.2 \\
& Male & 144 & 36.8 \\
& Department of Science Education (SE) & 36 & 9.2 \\
& Department of Primary Teaching Education (PTE) & 43 & 11.0 \\
& Department of Social Sciences Education (SSE) & 53 & 13.6 \\
& Department of Pre-school Education (PE) & 67 & 17.1 \\
Department & Department of Turkish Language Education (TLE) & 35 & 9.0 \\
& Department of Psychological Counselling and Guidance Education (PCGE) & 49 & 12.5 \\
& Department of English Language Education (ELE) & 48 & 12.3 \\
& Department of German Language Education (GLE) & 22 & 5.6 \\
& Department of Fine Arts Education (FAE) & 17 & 4.3 \\
& Department of Music Education (ME) & 21 & 5.4 \\
Academic Success & Medium & 130 & 33.2 \\
& Ligh & 148 & 37.9 \\
& Low & 113 & 28.9 \\
& Total & 391 & 100.0 \\
\hline
\end{tabular}

\subsection{Data Collection Instruments}

As data collection instruments, "The Group Embedded Figures Test" which was developed by Witkin, Oltman, Raskin and Karp [4] and adapted into Turkish by Guler Okman was administered to define prospective teachers' cognitive style in the study. On the other hand "The Revised Two Factor Study Process

IJERE Vol. 7, No. 4, December 2018 : 285 - 293 
Questionnaire" that was developed by Biggs, Kember and Leung [9] and by Onder and Besoluk [10] who assesded validity and reliability was used to reveal prospective teachers' learning approaches. Personal Information Form was developed by the researcher to gather demographic data from the participants.

The Group Embedded Figures Test consists of three sections. In the first section that is not included for the score, there are 7 complex figure questions; in the second and third sections that are included for the score, there are 9 complex figures questions for each one of the sections. In the test, it is required to find simple figures and highlight them in the complex figures. The highest score that can be got in the test is 18 . If the score of the test is getting high, it means field-independent cognitive style; if the score is lower and lower, it means field-dependent cognitive style. The participants who get 0-8 points in this test are defined as fielddependent; the others who got 12-18 points are evaluated as field-independent. Additionally, the participants who get 9-11 points are defined as neutral group who can have both of the cognitive styles.

The scale developed by Biggs, Kember and Leung [9] was called as "The Revised Two Factor Study Process Questionnaire" and it consists of two dimensions (Surface and Deep), there are two subdimensions for each dimensions and it is a 5-Likert type scale. The score of the main dimensions is calculated via sub-dimensions. It is interpreted that which dimension has higher score; the participants can use the learning approach in that dimension.

\subsection{Data Analysis}

The data collected via data collection instruments was analyzed via SPSS-20 package program. Firstly, in order to determine the distribution for the variables, percentage and frequency tests were used. Then, normality and homogeneity of the data were tested. For the aim of determining the normality of the data, Kolmogorov-Smirnov test was used. Buyukozturk [11] stated that if the number of the group has been over 50, normality is tested via Kolmogorov-Smirnov (K-S) test. Since the number of the participants in the study is over than $50(\mathrm{~N}=391)$, Kolomogorov-Smirnov test was preferred as the normality test. Additionally, in order to determine the homogeneity of the group, Levene's Test for Equality of Variances was used. For the aim of determining cognitive styles and learning approaches of the participants; frequency, arithmetic mean, standard deviation, minimum and maximum scores were calculated. As a result of the normality test, it was determined that cognitive styles, deep learning dimension and surface learning dimension of the participants were not seen as normal rates $(\mathrm{p}<.05)$. Because the normality of the participants was not suitable, Mann Withney U test was used. For the variables more than two, Kruskall Wallis test was used. Accordingly, for the aim of determining the directions of the differences in multiple variables, Mann Whitney-U test was used. In order to determine the relationship between cognitive styles and learning approaches, Spearman Brown's Rank correlation Coefficient was used. For the mean scores of statistical data, $\mathrm{p}=.05$ level was taken as basis.

\section{RESULT AND DISCUSSION}

For the aim of answering the first research question "What are the cognitive styles of pre-service teachers?" minimum-maximum scores, arithmetic mean, percentage and frequency analysis was used. The results of those were given in Table 2 .

When Table 2 was examined, it was seen that $56.8 \%$ of the participants were field-dependent and $43.2 \%$ of the participants were field-independent. Accordingly, the average scores of the pre-service teachers for cognitive styles were calculated as 9.46 .

Table 2. The cognitive style scores and cognitive styles of the pre-service teachers

\begin{tabular}{cccccccccc}
\hline & \multirow{2}{*}{$\mathrm{N}$} & \multirow{2}{*}{ Min. } & \multirow{2}{*}{ Max. } & $\overline{\mathrm{X}}$ & $\mathrm{Ss}$ & \multicolumn{2}{c}{ Field-dependent } & \multicolumn{3}{c}{ Field-independent } \\
& & & $\mathrm{N}$ & $\%$ & $\mathrm{~N}$ & $\%$ \\
\hline Cognitive Style & 391 & 1.00 & 18.00 & 9.46 & 4.37 & 222 & 56.8 & 169 & 43.2 \\
\hline
\end{tabular}

In the second sub-problem, it was searched that whether there was a mean difference of the preservice teachers' cognitive styles in terms of their gender, department and academic success. The related results were given in Table 3, 4 and 5 .

Table 3. Mann Whithey-U test results of the pre-service teachers' cognitive style scores for gender distribution

\begin{tabular}{cccccc}
\hline Groups & $\mathrm{N}$ & Rank Average & Total Rank & $\mathrm{U}$ & $\mathrm{p}$ \\
\hline Female & 247 & 193.21 & 47722.50 & 17094.50 & .518 \\
Male & 144 & 200.79 & 28913.50 & & \\
\hline
\end{tabular}

The Effects of Pre-service Teachers' Cognitive Styles on Learning Approaches (Sedat Altintaş) 
When Table 3 was examined, it was seen that there was not a mean difference between the preservice teachers' cognitive styles in terms of their genders $(\mathrm{p}>.05)$.

Table 4. Kruskall Wallis test results of the pre-service teachers' cognitive styles in terms of their departments

\begin{tabular}{ccccccccc}
\hline Scale & Rank no & Groups & $\mathrm{N}$ & Rank Average & $\mathrm{Sd}$ & $x^{2}$ & $\mathrm{p}$ & Mean Difference \\
\hline & 1 & SE & 36 & 168.10 & & & & \\
& 2 & PTE & 43 & 213.10 & & & & \\
& 3 & SSE & 53 & 164.38 & & & & $1-4 ; 1-5 ; 1-6 ; 1-$ \\
Cognitive Style & 4 & PE & 67 & 221.90 & & & & $9 ; 2-3 ; 2-5 ; 2-9 ; 3-$ \\
& 5 & TLE & 35 & 129.49 & 9 & 45.132 & .000 & $4 ; 3-6 ; 3-9 ; 4-5 ; 4-$ \\
& 6 & PCGE & 49 & 215.33 & & & & $9 ; 4-9 ; 5-6 ; 5-8 ; 5-$ \\
& 7 & ELE & 48 & 179.13 & & & & $9 ; 5-10 ; 6-9 ; 7-9 ; 8-$ \\
& 8 & GLE & 22 & 192.09 & & & & \\
& 9 & FAE & 17 & 311.35 & & & & \\
\hline
\end{tabular}

When Table 4 was examined, it was seen that there was a mean difference in terms of pre-service teachers' departments $(\mathrm{Sd}=9, \mathrm{~N}=391, \mathrm{x} 2=45.132, \mathrm{p}<.05)$. In order to determine the difference for the groups, Mann Whitney-U test was used. The results of the test which gave the differences for each departments were given in Table 4.

Table 5. Kruskall Wallis test results of the pre-service teachers' cognitive styles in terms of their

\begin{tabular}{ccccccc}
\multicolumn{7}{c}{ academic success } \\
\hline Scale & Groups & $\mathrm{N}$ & Rank Average & $\mathrm{Sd}$ & $\mathrm{x} 2$ & $\mathrm{p}$ \\
\hline \multirow{3}{*}{ Cognitive Style } & High & 130 & 181.59 & & & \\
& Medium & 148 & 202.76 & 2 & 3.235 & .198 \\
& Low & 113 & 203.73 & & & \\
\hline
\end{tabular}

When Table 5 was examined, it was seen that there was not a mean difference between the scores of the pre-service teachers in terms of their academic success $(\mathrm{p}>.05)$.

For the aim of answering the third research question "What are the learning approaches of preservice teachers?"; minimum-maximum scores, arithmetic mean, percentage and frequency analysis was used. The results of those were given in Table 6.

Table 6. The learning approaches scores and learning approaches of the pre-service teachers

\begin{tabular}{cccccccccc}
\hline & \multirow{2}{*}{$\mathrm{N}$} & Min. & Max. & $\overline{\mathrm{X}}$ & $\mathrm{Ss}$ & $\mathrm{N}$ & Deep & \multicolumn{3}{c}{ Surface } \\
Deep Learning & 391 & 15 & 48 & 30.09 & 5.44 & \multirow{2}{*}{208} & \multirow{2}{*}{53.2} & \multirow{2}{*}{183} & \multirow{2}{*}{46.8} \\
Surface Learning & 391 & 13 & 47 & 28.74 & 6.92 & & & \\
\hline
\end{tabular}

When Table 6 was examined, it was seen that $53.2 \%$ of the participants preferred deep learning approach and $46.8 \%$ of the participants preferred surface learning approach. The general average of the participants who preferred deep learning approach was determined as 30.09 and the others' score was determined as 28.74 .

In the fourth sub-problem, it was searched that whether there was a mean difference of the preservice teachers' learning approaches in terms of their gender, department and academic success. The related results were given in Table $7,8,9$ and 10 .

Table 7. Mann Whithey-U test results of the pre-service teachers' learning approaches scores for

\begin{tabular}{cccccccc}
\multicolumn{7}{c}{ gender distribution } \\
\hline Scale & Groups & $\mathrm{N}$ & Rank average & Total Rank & $\mathrm{U}$ & $\mathrm{p}$ \\
\hline Deep Learning & Female & 247 & 190.66 & 47092.50 & 47092.50 & .220 \\
& Male & 144 & 205.16 & 29543.50 & & \\
Surface Learning & Female & 247 & 191.67 & 47342.50 & 16714.50 & .321 \\
& Male & 144 & 203.43 & 29293.50 & & \\
\hline
\end{tabular}

IJERE Vol. 7, No. 4, December 2018: 285-293 
When Table 7 was examined, it was seen that there was not a mean difference between the preservice teachers' preferences for learning approaches in terms of their genders ( $p>.05)$.

Table 8. Kruskall Wallis test results for the pre-service teachers' deep learning approach scores in different departments

\begin{tabular}{|c|c|c|c|c|c|c|c|c|}
\hline Scale & Rank no & Groups & $\mathrm{N}$ & Rank average & $\mathrm{Sd}$ & $x^{2}$ & $\mathrm{p}$ & $\begin{array}{c}\text { Mean } \\
\text { difference }\end{array}$ \\
\hline \multirow{10}{*}{ Deep Learning } & 1 & $\mathrm{SE}$ & 36 & 234.28 & \multirow{10}{*}{9} & \multirow{10}{*}{46.424} & \multirow{10}{*}{.000} & \multirow{10}{*}{$\begin{array}{c}1-2 ; 1-4 ; 1-7 ; 2- \\
3 ; 2-5 ; 3-4 ; 3- \\
6 ; 3-7 ; 3-8 ; 3- \\
10 ; 4-5 ; 4-7 ; 5- \\
7 ; 6-7 ; 7-8 ; 7- \\
9 ; 7-10\end{array}$} \\
\hline & 2 & PTE & 43 & 169.29 & & & & \\
\hline & 3 & SSE & 53 & 257.22 & & & & \\
\hline & 4 & $\mathrm{PE}$ & 67 & 173.63 & & & & \\
\hline & 5 & TLE & 35 & 224.10 & & & & \\
\hline & 6 & PCGE & 49 & 195.78 & & & & \\
\hline & 7 & ELE & 48 & 126.51 & & & & \\
\hline & 8 & GLE & 22 & 188.80 & & & & \\
\hline & 9 & FAE & 17 & 225.32 & & & & \\
\hline & 10 & $\mathrm{ME}$ & 21 & 198.29 & & & & \\
\hline
\end{tabular}

Table 9. Kruskall Wallis test results for the pre-service teachers' surface learning approach scores in different departments

\begin{tabular}{|c|c|c|c|c|c|c|c|c|}
\hline & Rank no & Groups & $\mathrm{N}$ & Rank Average & $\mathrm{Sd}$ & $x^{2}$ & $\mathrm{p}$ & $\begin{array}{c}\text { Mean } \\
\text { Difference }\end{array}$ \\
\hline \multirow{10}{*}{ Surface Learning } & 1 & $\mathrm{SE}$ & 36 & 121.68 & \multirow{10}{*}{9} & \multirow{10}{*}{26.272} & \multirow{10}{*}{.002} & $1-2 ; 1-3 ; 1-4 ; 1-$ \\
\hline & 2 & PTE & 43 & 218.85 & & & & $5 ; 1-6 ; 1-7 ; 1-$ \\
\hline & 3 & SSE & 53 & 173.53 & & & & $8 ; 1-10 ; 2-3 ; 3-$ \\
\hline & 4 & PE & 67 & 217.56 & & & & $4 ; 3-8$ \\
\hline & 5 & TLE & 35 & 194.41 & & & & \\
\hline & 6 & PCGE & 49 & 214.67 & & & & \\
\hline & 7 & ELE & 48 & 199.25 & & & & \\
\hline & 8 & GLE & 22 & 234.82 & & & & \\
\hline & 9 & FAE & 17 & 184.82 & & & & \\
\hline & 10 & ME & 21 & 184.57 & & & & \\
\hline
\end{tabular}

When Table 8 and 9 was examined, it was seen that there was a mean difference in terms of surface and deep learning approaches of the pre-service teachers who were in different departments. In order to determine in which departments this difference was found, Mann Whithey- $U$ test was used. As a result of that test, the mean differences between different departments were given in Table 8 and 9 .

When Table 10 was examined, it was seen that there was a mean difference for deep and surface learning approaches of the pre-service teachers in terms of their academic success. In order to determine the groups of differences, Mann Whitney-U test was used. The results of this test were given in Table 10.

Table 10. Kruskall Wallis test results for the pre-service teachers' learning approaches in terms of

\begin{tabular}{cclcccccc}
\multicolumn{10}{c}{ academic success } \\
\hline Scale & Rank no & Groups & $\mathrm{N}$ & Rank Average & Sd & $x^{2}$ & $\mathrm{p}$ & Mean Difference \\
\hline \multirow{3}{*}{ Deep Learning } & 1 & High & 130 & 234.52 & & & & \\
& 2 & Medium & 148 & 181.85 & 2 & 23.384 & .000 & $1-2 ; 1-3$ \\
& 3 & Low & 113 & 170.22 & & & & \\
\hline \multirow{3}{*}{ Surface Learning } & 1 & High & 130 & 172.86 & & & & \\
& 2 & Medium & 148 & 202.51 & 2 & 8.855 & .012 & $1-2 ; 1-3$ \\
& 3 & Low & 113 & 214.10 & & & & \\
\hline
\end{tabular}

For the aim of determining whether there was a mean relationship between the cognitive styles and learning approaches of the pre-service teachers, Spearman Brown's Rank Correlation Coefficient was used. The results were given in Table 11 . 
Table 11. Spearman Brown's Rank Correlation Coefficient results of the pre-service teachers' scores for cognitive styles and learning approaches

\begin{tabular}{ccccc}
\hline & & Cognitive Style & Deep Learning & Surface Learning \\
\hline \multirow{3}{*}{ Cognitive Style } & $\mathrm{N}$ & 391 & 391 & 391 \\
& $\mathrm{r}$ & 1.000 & $-.119^{*}$ & .095 \\
& $\mathrm{p}$ & & .019 & .062 \\
\hline$* \mathrm{p}<.05$ & & &
\end{tabular}

When Table 11 was examined, it was seen that there was a mean difference between the pre-service teachers' deep learning approach and cognitive style in a negative direction.

As a result of this finding, it was seen that when the scores of the participants on cognitive styles have been higher, their preferences for deep learning approach have been getting low. Additionally, there was a relationship that was not mean in the scores of the pre-service teachers' cognitive styles and surface learning approach in a positive direction.

At the end of the study, it was determined that $56.8 \%$ of the participants had field-dependent and $43.2 \%$ of them had field-independent cognitive style. In was found that most of the pre-service teachers had field-dependent cognitive style. This result of the study was seen as parallel to the studies conducted by other studies $[12,13]$. Both the results of this study and the studies have shown that the learners have generally field-dependent cognitive style.

It was seen that there was not a mean difference between the genders and cognitive styles of the preservice teachers. This result was similar to the results of the studies in this field $[14,15]$. In this study, it was found that there was a mean difference between the departments and cognitive styles of the pre-service teachers. The reason of this difference can be a number of different variables. Cognitive styles are different from basic attitudes that are acquired in the daily life or learnt by environment. In this sense, cognitive styles are learnt in a process and they have a personality that is shaped via [16]. For this reason, it can be said that the education before higher education, past experiences, socio-economic status and social environment have an effect on the cognitive styles of the pre-service teachers. At the end of the study, it was seen that there was not a mean difference between the academic success and cognitive styles of the pre-service teachers. The reason of this result can be the lack of teaching techniques which have been designed for the different cognitive styles of the learners and it can be the lack of awareness of the learners on their own cognitive styles. Sahin [17] stated in a study that the teaching activities that have been designed as considering the field-dependent and field-independent cognitive styles of the learners could be helpful for permanence in learning process.

It could be said that the pre-service teachers mainly preferred deep learning approach instead of surface learning. The reason of preferring both of the learning approaches could be different teaching strategies, assessment methods and the contents of the courses that have been given in the higher education. This result of the study was similar to the some other studies in this field $[18,19,20]$.

At the end of the study, it was seen that there was not a mean difference between the gender and learning approaches of the pre-service teachers and it could be said that gender was not a meaningful variable for learning approaches. This result of the study was similar to the other studies in this field [21, 22, 23]. Additionally, the results of the study showed that there was a mean difference between the departments and learning approaches of the pre-service teachers in terms of deep learning and surface learning. This result of the study was similar to the results of the some other studies in this field [2, 12, 20, 23]. As for the reason of this difference, it could be said that the perceptions of the pre-service teachers in different departments could cause having different learning approaches. Additionally, different education programs, the quality of the instructors, different teaching materials and teaching techniques could be the reasons of this difference in different departments. In this study, it was seen that there was mean difference between the academic success and the learning approaches of the pre-service teachers in terms of deep and surface learning. It could be said that the pre-service teachers who preferred deep learning approach were more successful than the others who preferred surface learning approach. Gijbels and et.al [24] stated that deep learning approach was related to high learning products, however surface learning approach was related to low learning products. Additionally, Zeegers [25] noted that deep learning approach could affect learning performance positively. The results of the some other studies [26, 27, 28] could support the results of this study in this sense.

At the end of the study, it was seen that there was a difference that was not mean for study between the cognitive styles and surface learning approaches of the pre-service teachers and it was a positive directed and low level difference for the study. Additionally, there was a mean difference between the cognitive styles and deep learning approach of the pre-service teachers and it was a negative directed and low-level difference for the study. The learners who have field-independent cognitive style need communicate with their teachers or other learners less than the others who have field-dependent cognitive style [16]. The learners who prefer

IJERE Vol. 7, No. 4, December 2018: 285-293 
deep learning approach, on the other hand, prefer communicating actively [28]. This finding can be the reason of preferring deep learning approach by the learners who had field-dependent cognitive style. Fielddependent learners could control themselves and they could pay attention some themes even if they were not interested in them [16]. The learners who prefer deep learning approach, however, could direct their durations correctly and they could have enough time to pay attention for some themes [28]. It was seen that some of the characteristics of the pre-service teachers who had field-dependent cognitive style were similar to the characteristics of the pre-service teachers who preferred deep learning approach. In the literature, the results of the studies on the field of field-dependent and field-independent or deep/surface learning approaches could support the results of the current study. It could be said that the reason of this result could be the lack of information about the individual differences and cognitive styles in educational programs in faculties of education.

\section{CONCLUSION}

It was seen that 222 pre-service teachers from 391 of the total number had field-dependent cognitive style and 169of them had field-independent cognitive style. At the end of the study, it was seen that there was not a mean difference between the gender or academic success and cognitive styles of the pre-service teachers. It was seen that there was a mean difference between the departments and cognitive styles of the pre-service teachers who had been participated in this study. There was mean difference between the preservice teachers in the Department of Fine Arts Education and the others; it was a difference in countenance of the participants in the Department of Fine Arts Education.

In this study, it was found that 208 of the participants preferred deep learning approach and 183 of them preferred surface learning approach. It was also seen that there was a not a mean difference between the gender and learning approaches. The pre-service teachers in the Departments of Science Education, Social Science Education, Turkish Language Education, fine Arts Education and Music Education heavily preferred deep learning approach; and the others in the Departments of Primary School Education, Pre-school Education, English Language Teaching Education and German Language Teaching Education heavily preferred surface learning approach. The pre-service teachers who were successful academically could generally prefer deep learning approach; however the others who had low academic success preferred surface learning approach.

It was seen that when the pre-service teachers' options began to be closer to field-independent cognitive style, their preferences were closer to surface learning approach and when their cognitive style was closer to field-dependent cognitive style, their preferences were seen as deep learning approach.

\section{SUGGESTION}

It is believed that in order to improve the pre-service teachers both in their social life and professional life, studies in the field of individual differences can be enhanced by researchers. It is thought that instructors in faculties of education should be knowledgeable about different cognitive styles of their learners and they should organize their teaching processes via suitable cognitive styles.

According to the results of the study, it was seen that the pre-service teachers who preferred deep learning approach had higher academic success. It is believed that if the teaching environment is organized via suitable techniques, the preferences of the pre-service teachers who preferred surface learning approach can be changed into deep learning approach.

Some scientific studies can be conducted in order to improve the effectiveness of the cognitive styles and learning approaches. There can be some scientific studies on the fields of individual differences such as cognitive styles or learning styles; learning and studying lesson techniques.

\section{ACKNOWLEDGMENT}

This paper has been granted by the Muğla Sitkı Koçman University Research Projects Coordination Office through Project Grant Number: 15/025. This article held in Muğla on 31 may to 3 June 2016 were presented as oral presentations at the III nd International Eurasian Educational Research Congress.

\section{REFERENCES}

[1] Summerviller, J. "Role of Awareness of Cognitive Style in Hypermedia". International Journal of Educational Technology, vol/issue: 1(1), 1999.

[2] Ekinci, N. "Universite ogrencilerinin ogrenme yaklasimlari", Egitim ve Bilim, vol/issue: 34(151), 74-88, 2009.

The Effects of Pre-service Teachers' Cognitive Styles on Learning Approaches (Sedat Altintaş) 
[3] Witkin, H. A., Moore, C. A., Goodenough, D. R. \& Cox, P. W. "Field-Dependent and Field-İndependent Cognitive Styles and Their Educational İmplications", Review of Educational Resarch, vol: 47, 1-64, 1977

[4] Witkin, H. A., Oltman, P. K., Raskin, E., \& Karp, S. A.. "The Group Embedded Figures Test”, Palo Alto, CA: Consulting Psychological Press, 1971.

[5] Marton, F. \& Saljo, R. "On qualitative differences in learning İ: -Outcome \& process", British Journal of Educational Psychology, vol: 46, 4-11, 1976

[6] Hall, M., Ramsay, A. \& Raven, J. "Changing the Learning Environment to Promote Deep Learning Approaches in First-Year Accounting Students”, Accounting Education, vol/issue: 13(4), 489-505, 2004.

[7] Sabzevari, S., Abbaszade, A. \& Borhani, F. "The Assessment Methods and Learning Approaches in Nursing Students of Kerman University of Medical Sciences in Iran", Creative Education, vol/issue: 4 (02), 160, 2013.

[8] Karasar, N. "Bilimsel Arastirma Yontemi", Nobel Yayin Dagitim: Ankara, 2012.

[9] Biggs, J. B., Kember, D., \& Leung, D. Y. P. "The revised two factor study process questionnaire: R-SPQ-2F", British Journal of Educational Psychology, vol: 71, 133-149, 2001.

[10] Beşoluk, Ş. ve Önder, İ. "Öğretmen Adaylarının Öğrenme Yaklaşımları, Öğrenme Stilleri ve Eleştirel Düşünme Eğilimlerinin İncelenmesi”, İlköğretim Online, vol/issue: 9(2), 679-693, 2010.

[11] Büyüköztürk, Ş. "Sosyal Bilimler İçin Veri Analizi El Kitabı. (17. Basım)", Pegem Akademi Yayınları: Ankara, 2012.

[12] Altun, A. "Ogretmen Adaylarinin Bilissel Stilleri ile Bilgisayara Yonelik Tutumlari Arasindaki İliskinin İncelenmesi”, The Turkish Online Journal of Educational Technology - TOJET, vol/issue: 2 (1), 56-62, 2003.

[13] Kupcu, A. R. \& Ozdemir, A. S. "Ilkogretim Ogrencilerinin Bilissel Stil, Cinsiyet ve Orantisal Dusunme Seviyelerine Gore Oranti İliskili Problem Cozme Basarilari”, Kastamonu Egitim Dergisi, vol/issue: 20(2), 451-472, 2012.

[14] Brenner, J. "An analysis of students` Cognitive Styles in Asynchronous Distance Education Courses", Inquiry, vol/issue: 1(1), 37-44, 1997.

[15] Celik, O. "Uzaktan Ogrenme Ortaminin Ogrencilerin Bilissel Stillerine Gore Bilissel Senaryo Olusturma Becerilerine, Akademik Basarilarina ve Ogrenmenin Kaliciligina Etkisi”, Unpublished Master Thesis, Mugla University, 2010.

[16] Guven, B. "Ilkogretim 5. Sinif Sosyal Bilgiler Dersinde Alan Bagimlilik-Alan Bagimsizlik Bilissel Stil Boyutlarina Uygun Olarak Hazirlanan Ogretim Etkinliklerinin Akademik Basari ve Tutumlar Uzerindeki Etkisi”, Unpublished PhD Thesis, Anadolu University, 2003.

[17] Sahin, D. "Ilkogretim 5. Sinif Fen ve Teknoloji Dersinde Alan Bagimlilik Alan Bagimsizlik Bilissel Stil Boyutlarina Gore Hazirlanan Ogretim Etkinliklerinin Akademik Basari ve Tutumlar Uzerindeki Etkisi", Unpublished Master Thesis, Gazi University, 2009.

[18] Senemoglu, N. "College of Education Students' Approaches to Learning and Study Skills", Education and Science, vol/issue: 36(160), 65-80, 2011.

[19] Tural Dincer, G. \& Akdeniz, A. R. "Examining Learning Approaches of Science Student Teachers According to the Class Level and Gender”, Online Submission, vol/issue: 5(12), 54-59, 2008.

[20] Olpak, Y. Z. \& Korucu, A. T. "Ogrencilerin Ders Calisma Yaklasimlarinin Farkli Degiskenler Acisindan İncelenmesi”, Ahi Evran Universitesi Kirsehir Egitim Fakultesi Dergisi, vol7issue: 15(1), 333-347, 2014.

[21] Chan, K. "Hong Kong teacher education students' epistemological beliefs and approaches to learning", Research in Education, vol: 69, 36-50, 2003.

[22] Sezgin-Selcuk, G., Caliskan, S. \& Erol, M. "Fizik Ogretmen Adaylarinin Ogrenme Yaklasimlarinin Degerlendirilmesi”, Gazi Egitim Fakultesi Dergisi, vol/issue: 27(2), 25-41, 2007.

[23] Ellez, A. M. \& Sezgin, G. "Ogretmen adaylarinin ogrenme yaklasimlari”, Orta Dogu Teknik Universitesi V. Ulusal Fen Bilimleri ve Matematik Egitimi Kongresi, Ankara, 2002.

[24] Gijbels, D., Dochy, F., Van den Bossche, P. \& Segers, M. "Effects of Problem-Based Learning: A Meta-Analysis from the Angle of Assessment", Review of Educational Research, vol/issue: 75 (1), 27-61, 2005.

[25] Zeegers, P. "Approaches to Learning in Science: A Longitudinal Study", British Journal of Educational Psychology, vol/issue: 71 (1), 115-132, 2001.

[26] Bernardo, A. B. I. "Approaches to Learning and Academic Achievement among Filipino Students", The Journal of Genetic Psychology, vol: 164, 101-114, 2003.

[27] Sadler-Smith, E. "Cognitive Style and Learning in Organizations", R. J. Riding, \& S. G. Rayner icinde, International Perspectives on İndividual Difference. Stamford: Ablex Publishing Corporation, 2000.

[28] Yildiz, B. "Yabanci Diller Yuksekokulu İngilizce Hazirlik Sinifi Ogrencilerinin Ogrenme ve Ders Calisma Yaklasimlarinin İncelenmesi”, Unpublished Master Thesis, Ege University, 2013

IJERE Vol. 7, No. 4, December 2018: $285-293$ 


\section{BIOGRAPHIES OF AUTHORS}

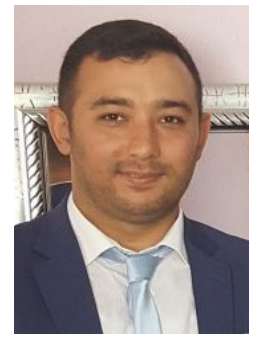

Sedat Altıntaş, researcher, has been studying for doctorate at Muğla Sitk1 Koçman University, Curriculum and Instruction Program. He has been working as a research assistant at Muğla Sitk1 Koçman University, Faculty of Education, Department of Curriculum and Instruction. His research interests are math education, curriculum development and assessment, teacher training, learning and teaching skills.

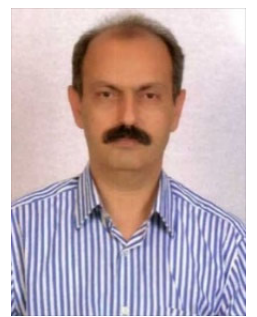

Prof. Dr. İzzet GÖRGEN completed his BA, MA and PhD Degrees at Hacettepe University, Curriculum and Instruction Program. He has been working at Muğla Sitkı Koçman University, Faculty of Education, Department of Curriculum and Instruction. His research interests are curriculum development and assessment, teacher training, learning and teaching skills. 